\title{
Tribe blasts 'exploitation' of blood samples
}

Rex Dalton, Vancouver

Nearly 20 years ago, Amerindians on Vancouver Island in Canada donated blood for research into the genetic causes of rheumatoid arthritis, a disease that is rampant in their tribe. Now they are incensed to discover that the specimens have been used for other research — including a project on the sensitive issue of the spread of lymphotropic viruses by intravenous drug abuse.

Leaders of the Nuu-chah-nulth (Nootka) tribe describe the research as another example of exploitation of indigenous peoples. Some have demanded the return of the samples. The case has opened a debate on what should happen to stored biological samples from completed projects, and whether they should be allowed to be moved between different research institutions.

The arthritis research was conducted at the University of British Columbia (UBC), andled by geneticist Ryk Ward, who collected the blood samples and took genealogical histories from the tribe. Ward left UBC in 1986 and took the Nuu-chah-nulth specimens with him, first to the University of Utah and then, in 1996, to the University of Oxford, UK, where he continues to head the Institute of Biological Anthropology. Unable to show a genetic basis for the tribe's arthritis with the tools available in the 1980s, Ward used the samples for other research projects, sharing data with many different collaborators. These projects yielded half a dozen published articles.

UBC officials confirm that the tribal participants did not give consent for research on subjects other than arthritis. Ward also acknowledges that he never obtained renewed consent from the tribe to take the blood samples with him for further studies. "The way people operated at the time," he told Nature, "it didn't cross anyone's mind - we didn't mean to be evil, and we are more careful now."

The genetics community is becoming more sensitive to the issue, and some institutions in Canada and the United States have recently tightened rules on consent and the use of stored samples. "But it remains a major concern," says Michael McDonald, a UBC ethicist who advises Canadian researchfunding agencies. "Researchers ship biological specimens all over, but we don't have good procedures for dealing with this."

In the wake of the Nuu-chah-nulth case, UBC and Utah have introduced policies that require researchers to obtain consent each time they wish to conduct new research on stored samples. And last January, Utah implemented another policy whereby study samples were declared to be university property, and cannot be removed by departing researchers without specific permission. "It is inappropriate for folks to drive away with biological samples," says geneticist Jeffrey Botkin,

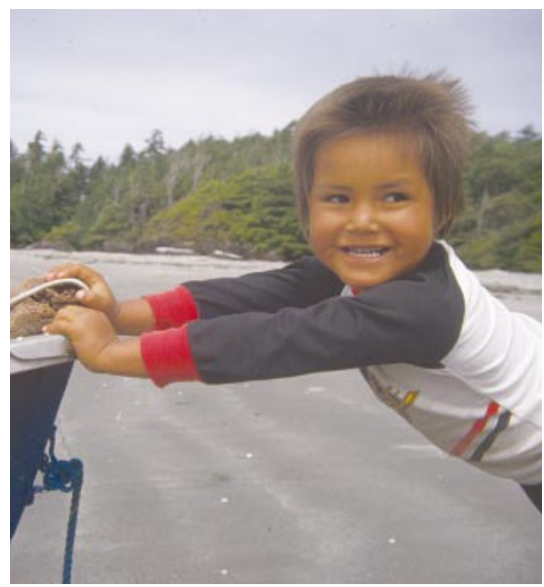

Members of Canada's Nuu-chah-nulth tribe are angry at the unsanctioned use of blood samples.

Utah's associate vice-president for research.

Laura Arbour, a UBC geneticist, is writing a case study on the Nuu-chah-nulth experience. The problem with genetic samples, she says, is that the research community has traditionally considered the DNA as a gift, when she says it really is only "loaned" under a very specific contract. And genetic research on Amerindians - who are much sought after for their distinctive genetic lineages - is even more sensitive, Arbour notes.

The Nuu-chah-nulth problem came to the attention of UBC authorities two years ago, after an indigenous peoples' newspaper reported tribal unrest over the use of their samples for non-arthritis research. Canadian geneticists and government officials have since held five workshops to review the case, and to develop better policies.

Among the proposals under consideration is a national tissue bank for genetic samples from First Nation tribes, who would govern the repository themselves. Some Canadian leaders question the practicality of such an enterprise, as it would be difficult to get the diverse tribes to agree a strategy.

International rules are needed, says McDonald, to ensure that human biological samples are respected - particularly now that the human genome has been sequenced, tempting more scientists to reach into freezers for stored samples for comparative analyses.

\section{Space station set for sky-high profile}

\section{David Adam, London}

Already faced with cost overruns and technical delays, officials overseeing the building of the International Space Station (ISS) are scratching their heads over a new problem - determining its 'values'. Desperate to boost funds for the project, the European and Canadian space agencies have enlisted the help of a public-relations company to develop a "branding and communications strategy" for the cash-strapped station.

"In the past, human spaceflight has wrongly retained an exotic and élitist image. With the ISS this is changing," explains Jörg Feustel-Büechl, director of manned spaceflight and microgravity at the European Space Agency (ESA). "The station offers companies and organizations the opportunity, for the first time, to exploit manned spaceflight for commercial purposes."

As well as focusing on the research and development community - many of whom, ESA says, are unaware of the station's potential - the agency is also targeting what it calls "newer kinds of space entrepreneurs" involved in marketing, entertainment and tourism.

Still, those looking at the station are unlikely to see a cola advert painted onto its side, says Nicholas Lunt, business development director with Ogilvy Public
Relations, the Brussels-based firm hired by ESA. "If you view this solely as painting logos on pieces of hardware then that misses the point of what sponsors are looking for," Lunt says. "We cannot pretend in any way that this is a Formula One car."

The firm - which Lunt says is a "360-degree communications agency" has signed a one-year deal to determine the brand position of the ISS, and to develop a communications strategy to put it into the public eye and raise its profile among the business community. “And we can't do that until we've identified the values of the station," he says.

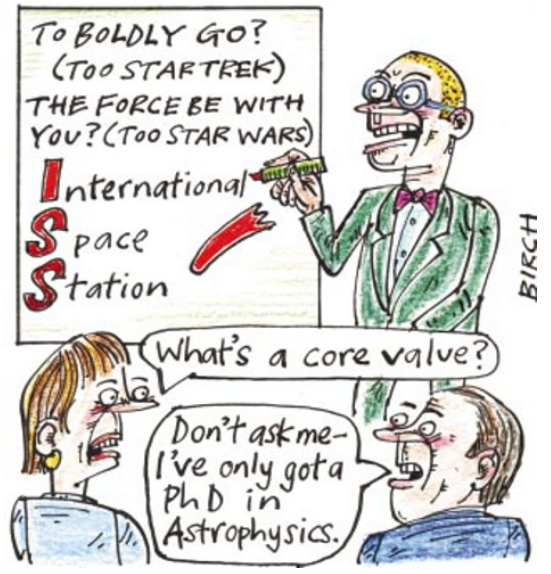

